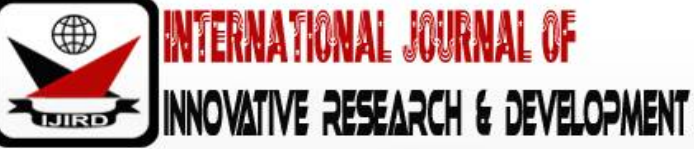

ISSN 2278 - 0211 (Online)

\section{Strategies Used by Teachers of English in Public Schools to Enhance Pupils' Performance on Primary School Leaving Examination in Magu District, Tanzania}

\author{
Debora Jigaba Maugo \\ Graduate Masters Student, Department of Education, Bujora Primary School, Magu, Tanzania \\ Joseph M. Malusu \\ Associate Professor, Department of Education, Mwenge Catholic University, Tanzania
}

\begin{abstract}
:
Pupils' Performance on PSLE in English language subject in public primary schools has been declining year after year. This study was conducted in Magu District to investigate Strategies used by teachers of English in public schools to enhance pupils' performance on Primary School Leaving Examination. The study was guided by 3 research questions. The study used Cross Sectional Survey and phenomenology designs. The sample of the study consisted of 141 respondents. The study used simple random sampling to select 10 schools, purposive and stratified sampling was used to select 120 pupils, purposive sampling technique was used to get 10 teachers of English while 10 head teachers and one (1) DEO were directly included due to their positions. The major instruments for data collection were questionnaire, observation guide, focus group discussion guide, interview guide, and document analysis guide. Validity of the instruments was determined through experts and Reliability coefficient was calculated by using Cronbach's Alpha and found to be 0.65 . Chi-Square was used to test the null hypothesis. Quantitative data were analyzed through frequency, percentages and presented in tables by the aid of Statistical Package for Social Sciences (SPSS). Qualitative data were analyzed through narration and quotations. The findings revealed that Strategies such as question and answer, group discussion, remedial classes and provision of frequent tests and examinations are used in teaching English language subject to enhance pupils' performance on PSLE. So, from the findings it was concluded that, there is a significant relationship between strategies used by teachers of English and pupils' performance on PSLE in public primary school.
\end{abstract}

Keywords: Strategies, teachers, pupils' performance and primary school leaving examination

\section{Introduction}

Primary school education is fundamental to the strengthening of higher levels of education, laying strong foundation in scientific and technological literacy and capacity and thus a means to self-reliance for personal and national development. Primary education is intended to enable every child to acquire knowledge and basic skills of literacy, communication, numeracy and problem solving as well as attitudes needed for development to full capacity. Furthermore, it aims to provide the child with the foundation of self-initiative, self-advancement, and self-confidence and to prepare a child for secondary level education (URT, 1995).

Roy-Campbell and Qorro (1997) assert that education is carried out largely through the medium of language; thus, language is very significant in the education process. The Association for the Development in Africa (ADEA) (2005) argued that, language is not everything in education, but without language, everything is nothing in education. Moreover, Language plays a crucial role in learning, and if the learner is handicapped in the language of instruction, then learning may not take place at all as the teacher and the learner will not be communicating (Malekela, 2003). In March 1967, the government of Tanzania declared that English shall be taught as a compulsory subject in primary schools (Biswalo, 2010).

In educational context, effective teaching and learning of English language depends on different factors, and among those factors is the application of effective teaching and learning strategies. With a variety of different skill levels in every classroom, teachers of English must employ effective strategies that allow each pupil to learn the subject. Whether the class focuses on literature, grammar, or language skills, teaching strategies will come in handy for many teachers of English. In order for the strategies used for teaching to be effective, Adunola (2011) observes that teachers need to be familiar with numerous teaching strategies that take recognition of the magnitude of complexity of the concepts to be covered. Vuzo (2010) reported that, it is through interactions with each other that teachers and students work together to create intellectual and practical activities that shape both the form and the content of the target subject.

In Tanzania the performance in English subject has been declining year after year. As a result, the Ministry of Education in cooperation with "Tawala za Mikoa na Serikali za Mitaa" (TAMISEMI) conducted Student Teacher Enrichment Programme (STEP) for teachers of English in order to improve teaching and learning strategies that can enhance pupils' 
performance on PSLE. The decline of Pupils' performance on Primary School Leaving Examination (PSLE) in English language subject among Tanzanian primary school pupils has drawn the attention of various education stakeholders such as educators, teachers and parents who have been complaining about the level of literacy acquired by pupils during their primary education especially in public primary schools where the majority of pupils attend. In this regard, (Uwezo, 2011, 2012; Roy-Campbell \& Qorro, 1997) reported that the levels of literacy in English language have been falling dramatically, leading to the turning out of primary school leavers who can neither read nor write a basic story in English.

English is by far the hardest subject for students. Many children reach Standard 7 without any English skills at all. By the time they complete primary school, half of the children (49.1\%) still cannot read a Standard 2 level English story, and far fewer are likely to be able to read at the Standard 7 level (Uwezo, 2015).

The education sector of Tanzania has the role of improving the provision of education by ensuring good learning outcomes whereby pupils' performance in English language subject should be observable and measurable. In order to measure the competences attained by standard seven pupils through the education system, National Examinations Council of Tanzania (NECTA) administers PSLE at the end of the seven years of Primary Education Programme (NECTA, 2009). While NECTA measures the competences attained by standard seven pupils in English language subject the results in this subject have remained at low performance for a long period. Nyamubi (2003) and Yohana (2012) reported that, studies carried out in Tanzania established that students' English language achievement in National Examinations has been poor for a long period of time. However, teaching is a useful way of facilitating and sharing knowledge, it does not at all times result in learning; this can be seen clearly in the painful discrepancy between what we think we have effectively taught and what pupils show they have learnt on their examination papers. Statistical data from NECTA show that in Magu District pupils' performance on PSLE in English language subject has been declining year after year.

Big Results Now (BRN) programme was launched in 2014 to enable lower achievers to increase their academic performance in order to enhance PSLE performance in English language subject. World Bank (2014) reports that, the government launched the BRN programme (2014-2018), which focuses on academic results and improving learning outcomes as a way to address the poor quality of education in Tanzania. The government has made some initiatives to improve pupils' performance on PSLE in English language subject, but the decline of pupils' performance on PSLE in English language subject still exists as Mesomapya (2016) reported that, after PSLE results released in 2016 the NECTA Executive Secretary said that performance in English subject declined between 0.39 and $12.51 \%$.

Therefore, the continued decline of pupils' performance in English language subject established the need to explore whether strategies used by teachers of English in teaching English language subject could lead to the increase of pupils' performance on PSLE in English language subject in Magu District.

\section{Statement of the Problem}

The decline of pupils' performance on PSLE in English language subject in public primary schools is a problem that has drawn the attention of various education stakeholders who have been complaining about the level of literacy acquired by pupils during their primary education. The Ministry of Education in cooperation with "Tawala za Mikoa na Serikali za Mitaa" (TAMISEMI) conducted Student Teacher Enrichment Programme (STEP) for teachers of English in order to improve teaching and learning strategies that can enhance performance on PSLE. World Bank (2014) reports that, the government launched the BRN programme (2014-2018), which focuses on academic results and improving learning outcomes as a way to address the poor quality of education in Tanzania.

Despite various strategies that have been used by the government to enhance pupils' performance on PSLE in English language subject, the decline of pupils' performance on PSLE in English language subject still persists in public primary schools in Magu District. The decline of English results on PSLE has been reflected in the concern voiced by government official -NECTA Executive Secretary in 2016 after PSLE results release when he said that performance in English subject declined between 0.39 and 12.51\% (Mesomapya, 2016). Roy-Campbell \& Qorro (1997) also reported on the falling levels of literacy in English language subject which lead to primary school leavers who can neither read nor write a basic story in English. Uwezo (2013) stated that while millions of children attend primary school, the learning outcomes continue to be very low. Pupils' performance is poor, especially in English; only 37 percent of primary-level pupils tested passed the English test.

English language is very significant because different sectors such as education, tourism, air transportation and high court depend on English language for transaction. Personnel in different sectors that depend on English language for transaction should have knowledge and skills in English language in order to provide better services to their clients.

The persistent decline of pupils' performance on PSLE in English language subject in public primary schools in Magu District established the need to find out how English language subject is taught in public primary schools in Magu District. Therefore, the current study investigated strategies used by teachers of English in public schools to enhance pupils' performance on primary school leaving examination in Magu District.

\section{Research Questions}

This study was guided by the following research questions:

- What strategies do teachers of English use in teaching English language subject to enhance pupils' performance on PSLE in public primary schools in Magu District?

- What challenges do teachers of English face in using teaching strategies to enhance pupils' performance on PSLE in English language subject in public primary schools in Magu District?

- What possible solutions should be taken by teachers of English to enhance pupils' performance on PSLE in English language subject in public primary schools in Magu District? 


\subsection{Research Hypothesis}

- H1: There is a significant relationship between strategies used by teachers of English and pupils' performance on PSLE in public primary schools in Magu District.

\section{Conceptual Framework}

The conceptual framework in this study shows strategies used by teachers of English in public primary schools to enhance pupils' performance on primary school leaving examination in English language subject. Teaching strategies in the context of the study is participatory strategies for facilitating pupils' learning and pupils' performance.

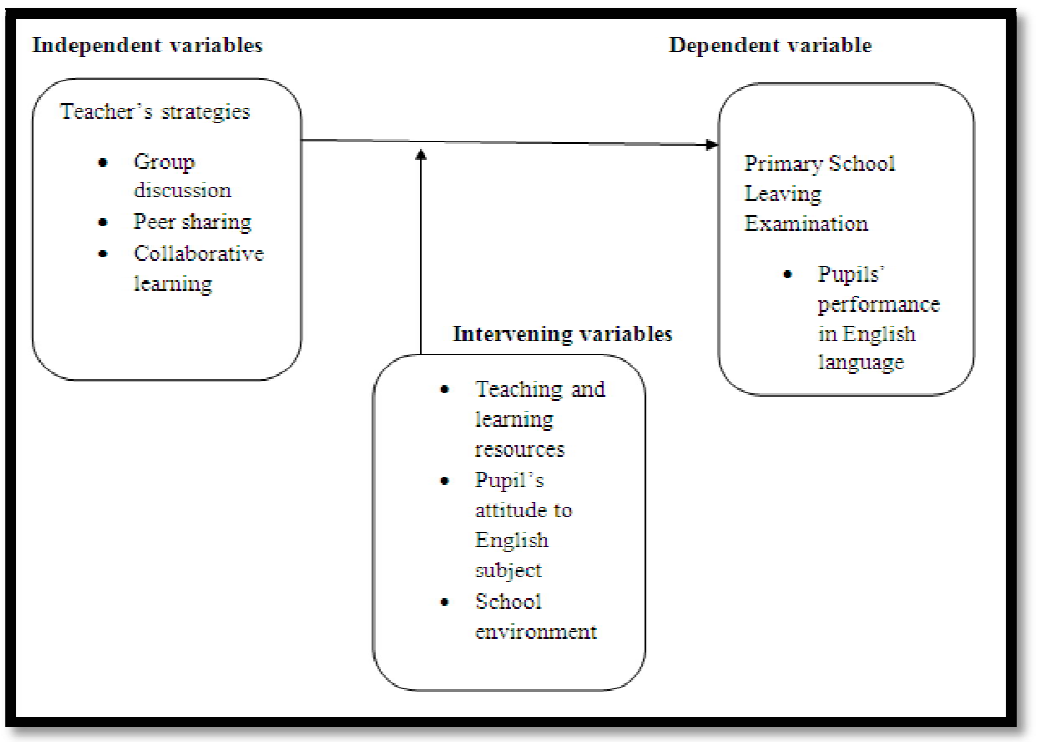

Figure 1: Conceptual Framework Derived From Constructivism Theory Source: Researcher, 2018

This conceptual framework guided the study about strategies used by teachers of English on pupils' performance on PSLE in English language subject. Figure 1 shows the interaction between the independent, intervening and dependent variables. Dependent variable which is pupils' performance on PSLE is a result of independent variables which are strategies such as group discussion and peer sharing used by teachers of English to enhance pupils' performance. These strategies alone cannot lead to pupils' performance on PSLE, but there are other factors such as teaching and learning resources and pupil's attitude to English subject which are intervening variables that should be in cooperated with independent variables so as to enhance pupils' performance on PSLE in English language subject.

\section{Literature Review} involved:

Different literatures were reviewed to support the discovery of reliable findings. The following studies were

\subsection{Strategies Used by Teachers of English to Enhance Pupils' Performance on PSLE}

Shi (2015) conducted a study in the United States exploring English Language Learners' Need and Learning Strategies at the post-secondary level in the university setting. Survey design and individual interviews and questionnaire were instruments used in the study. The findings showed that among different strategies such as compensation, metacognitive, social, cognitive, memory and affective strategies were used. It shows that compensation strategies (i.e. guessing meanings, using gestures), metacognitive strategies (i.e. planning for language tasks, self-evaluating one's progress, and monitoring error), social strategies (i.e. asking questions, cooperating with native speakers of the language, and becoming culturally aware) and cognitive strategies are the most often used strategies, while memory and affective strategy is the least often used strategy.

The study conducted by Mutai (2012) intended to identify the teaching strategies employed by English language teachers in secondary schools in Eldoret Municipality in Kenya. The study used a mixed method research design. The study used questionnaires, interviews, documentary data and non- participant observation for data collection. The study found that lecture and group discussions are the common methods employed by teachers in their teaching. Debating and drama or role play were not fully utilized. It was noted that there is unnecessary wastage of time during lessons. Secondary school English language teachers treat the issue of time rather casually. It was revealed that not only do teachers go to class late, but they also leave early or long after the bell. It seems teachers do not plan and allocate time for their oral questions, classroom responses and other activities appropriately.

\subsection{Challenges Teachers of English Face in Using Teaching Strategies}

O' Connor and Geiger (2009) conducted a study on challenges facing primary school educators of English second (or other) Language learners in the Western cape in South Africa. The study used mixed method descriptive design and the instruments used to collect data were questionnaire and 3 focus group discussion. The findings revealed that challenges 
that face primary school educators of English second (or other) Language are learner academic and socio emotional difficulties and shortage of educators who are able to speak isiXhosa.

Metto and Makewa (2014) conducted the study on learner centered teaching: Can it work in Kenyan public primary schools? The study sought to answer the issue on whether learner centered teaching can work in Kenyan public primary schools. The findings revealed that, despite the benefits of student-centered teaching, teachers cannot use these methods because of high teacher-pupil ratios and because the learners many of whom come from poor backgrounds, lack the necessary knowledge and motivation that suit the practice of learner-centered teaching and learning.

\subsection{Solutions to the Challenges Facing Teachers of English in Using the Strategies to Teach English Language Subject}

Bell and Bogan (2013) conducted a study on English Language Learners: Problems and Solutions Found in the Research of General Practitioners of Early Childhood. The findings show that basic solutions to support teaching practices are to offer staff development to the teachers that can increase their confidence and support them in their work. To group students according to their ability within the classroom provides the opportunity for appropriate materials to be used with the students to better match their needs and increases interactions and participation. Maintenance of home language within classroom practices. When learners receive instructions in their native language in concert with English the academics improve. This study examined solutions on how to teach and learn English language during early childhood while the current study investigated on the solutions to challenges teachers of English face in applying strategies to enhance pupils' performance on PSLE.

\subsubsection{Summary of Literature Review and Knowledge Gap}

Various empirical studies conducted in relation to strategies used by teachers of English on pupils' performance on PSLE in English language subject in different parts of the world have been reviewed. These studies were focused on different aspects related to teaching strategies at different levels of education. However, almost all literatures are different from the current study as far as the core theme is concerned. For instance, Shi (2015) conducted a study in United States exploring English Language Learners' Need and Learning Strategies at the post-secondary level in the university setting. The study did not relate to the strategies used by teachers of English to enhance performance on PSLE in English language subject in public primary schools. Mutai (2012) conducted a study that concentrated on the identification of teaching strategies employed by teachers of English language to teach English language in secondary level of education, but not strategies used by teachers of English in public schools to enhance pupils' performance on PSLE in public primary schools. All studies which have been reviewed do not answer the research questions of the current study because the previous studies have not addressed on strategies used by teachers of English in public primary schools to enhance pupils' performance on PSLE. Since none of the reviewed studies pay attention to strategies used by teachers of English in public schools to enhance pupils' performance on PSLE, this is a knowledge gap that this study filled by investigating strategies used by teachers of English in public schools to enhance pupils' performance on primary school leaving examination in Magu District, Tanzania.

\section{Research Designs and Methodologies}

This study used both quantitative and qualitative research designs in order to explore more information. Under quantitative approach, Cross- Sectional Survey design was used while under qualitative approach, phenomenology design was used in the study. Probability sampling procedures which is simple random sampling was used to get the sample of 10 public primary schools and stratified sampling procedures was used to obtain 12 pupils from each school based on their gender. Non- probability sampling procedure which is purposive sampling procedure was used to sample 10 teachers of English who taught English language subject in standard seven in 2018; and 120 standard VII pupils. Ten (10) head teachers and one (1) District Education Officer (DEO) were directly included in the study due to their positions. The total sample of the study included 141 respondents.

The main instruments that used in the study were: Questionnaire that was used for teachers, observation guide was used to observe participation of teachers and pupils in classroom activities, interview guide was used for head teachers and DEO, focus group discussion guide was used for pupils and documents analysis guide was used to collect data about teaching and learning documents and PSLE performance trends in English language subject at school level.

To ensure validity, the instruments used in the study were provided to the experts to check the relevance to the study. In order to estimate the reliability in quantitative approach, Cronbach's Alpha was used to determine the reliability of items from questionnaire which was administered to teachers of English. The reliability coefficient for questionnaire was 0.65 which showed that the instrument was reliable. In qualitative approach, Peer debriefing and methodological triangulations were used to determine reliability of items from qualitative instruments.

Quantitative data from questionnaire were analysed by using descriptive statistics (frequency and percentages) and presented in tables by the aid of Statistical Package for Social Sciences (SPSS) version 22. Chi - square was used to test the null hypothesis to determine the significant relationship between the strategies used by teachers of English in public schools and pupils' performance on PSLE in English language subject. The significance was tested at 0.05, level of significance. Qualitative data were analysed through narration and direct quotations. 


\section{Results and Discussion}

\subsection{Strategies Used by Teachers of English to Enhance Pupils' Performance on PSLE}

The study aimed to find out information about teaching strategies used by teachers of English on enhancing pupils' performance on PSLE in English language subject, teaching strategies mostly used, how teaching strategies teachers of English use enable pupils to acquire the four basic skills in English, teaching strategies that enhance pupils' performance on PSLE in English language and other strategies apart from classroom strategies that enhance pupils' performance on PSLE.

\subsubsection{Teaching Strategies on Enhancing Pupils' Performance on PSLE}

The study investigated if participatory teaching strategies enhance pupils' performance on PSLE in English language subject. Table 1 summarizes the findings.

\begin{tabular}{|c|c|c|}
\hline $\begin{array}{c}\text { Do Teaching Strategies Enhance } \\
\text { Pupils' Performance }\end{array}$ & Frequency (F) & Percent (\%) \\
\hline Yes & 7 & 70.0 \\
No & 3 & 30.0 \\
\hline
\end{tabular}

Table 1: Responses of Teachers of English about Participatory Teaching S Trategies on Enhancing Pupils' Performance on PSLE ( $\mathrm{N}=10$ ) Source: (Field Data, 2018)

Table 1 show that majority, 7 (70.0\%) of teachers of English pointed out that teaching strategies enhance pupils' performance on PSLE in English language subject. Three (3) (30.0\%) of teachers of English stated that teaching strategies do not enhance pupils' performance on PSLE in English language subject.

Majority of head teachers claimed that teaching strategies enhance pupils' performance on PSLE in English language subject. On the same opinion, DEO asserted that:

Teaching strategies especially participatory strategies enhance pupils' performance on PSLE in English language subject. (13th July, 2018)

The findings show that participatory teaching strategies enhance pupils' performance on PSLE in English language subject. Pupils are involved in different activities during the lesson hence understanding of subject matter that led to better performance in their examinations.

The findings concur with Fahraeus (2013) who argued that learner-centered instructional strategies promote deep and lasting learning. Dembo (1991) also argued that the use of learner-centered approaches in teaching require that learners play an active role in class so if the learners remain passive, it might force the teacher to resort to the traditional teacher-centered approach that is more accommodative to passive learners.

\subsubsection{Teaching Strategies Mostly Used by Teachers of English to Teach English Language Subject}

The study explored about strategies which are mostly used by teachers of English to teach English language subject in public primary schools in Magu District. Table 2 indicates the responses from teachers of English.

\begin{tabular}{|c|c|c|}
\hline Teaching Strategy & Frequency (f) & Percent (\%) \\
\hline Demonstration & 4 & 40.0 \\
\hline Question and answer & 7 & 70.0 \\
\hline Brain storming & 2 & 20.0 \\
\hline Group discussion & 7 & 70.0 \\
\hline Peer sharing & 1 & 10.0 \\
\hline Lecture & 1 & 10.0 \\
\hline Songs & 3 & 30.0 \\
\hline Storytelling & 2 & 20.0 \\
\hline Jigsaw & 1 & 10.0 \\
\hline Essay writing & 1 & 10.0 \\
\hline Role play & 1 & 10.0 \\
\hline Drama & 1 & 10.0 \\
\hline
\end{tabular}

Table 2: Responses of Teachers of English on Teaching Strategies Mostly Used to Teach English Language Subject $(\mathrm{N}=10)$ Source: (Field Data, 2018)

Table 2 indicates that 7 (70.0\%) of teachers of English stated that question and answer is mostly used to teach English language subject. Seven (7) (70.0\%) of teachers of English said that group discussion is mostly used to teach English language subject. Four (4) (40.0\%) of teachers of English argued that demonstration is mostly used to teach English language subject. The findings show that question and answer, demonstration and group discussion are the strategies which are mostly used by teachers of English to teach English language subject in public primary schools. Moreover, majority of head teachers responded that question and answer as well as group discussion are mostly used to teach English language subject. Few head teachers stated that strategies such as demonstration, brain storming and 
lecture are mostly used to teach English language subject. However, lecture is not allowed to use in primary school level due to that it does not involves pupils in learning.

Furthermore, DEO explained that:

Teachers of English mostly use participatory strategies such as question and answer, demonstration and group discussion. (13 th July, 2018)

Pupils also stated that strategies which are mostly used are question and answer, group discussion, demonstration, brain storming and peer sharing. During classroom observation, it was found out that question and answer, brainstorming and demonstration were mostly used. This implies that teachers of English use participatory teaching strategies although some strategies are not mostly used in teaching English language subject. While teachers of English use different participatory strategies in teaching and learning, they need to be aware on the ability of pupils and the content they present to pupils so that they can choose appropriate learner centred strategies to use during the lesson.

The findings are similar to Omari (1995), who argued that children in the classroom have greater differences hence using only one teaching strategy may be both monotonous and ineffective. Teaching strategies such as group work, reading silently or aloud, copying notes, listening to stories, writing composition and working out problems are encouraged to be used. In order to determine how pupils themselves learn English language, pupils responded that they learn English by using English Swahili dictionaries, reading English textbooks, story books and seeking help from the teacher for difficult words. The findings are in agreement with Dhillon and Wanjiru's (2013) who stated that learners use strategies such as: comprehension tactics, keeping vocabulary notebooks and using dictionaries and working in groups in their effort to learn English.

\subsubsection{Teaching Strategies Used by Teachers of English to Enable Pupils to Acquire the Four Basic Skills in English Language} Subject

The study also investigated on strategies which enable pupils to acquire the four basic skills in English language subject namely: listening, speaking, reading and writing. Teachers of English provided their views as indicated in Table 3 following:

\begin{tabular}{|c|c|c|}
\hline Strategies & Frequency (f) & Percent (\%) \\
\hline Drama & 4 & 40.0 \\
\hline Question and answer & 8 & 80.0 \\
\hline Essay writing & 2 & 20.0 \\
\hline Group discussion & 7 & 70.0 \\
\hline Storytelling & 6 & 60.0 \\
\hline
\end{tabular}

Table 3: Responses of Teachers of English on Teaching Strategies That Enable

Pupils to Acquire the Four Basic Skills in English Language Subject ( $\mathrm{N}=10$ )

Source: (Field Data, 2018)

The findings indicate that $8(80.0 \%)$ of teachers of English stated that question and answer enable pupils to acquire listening and speaking skills in English language. Seven (7) (70.0\%) of the teachers of English pointed out that group discussion enables pupils to acquire listening and speaking skills in English language. Six (6) (60.0\%) of the teachers of English revealed that story telling enables pupils to acquire listening and speaking skills in English language. Four (4) $(40.0 \%)$ of the teachers argued that drama enables pupils to acquire speaking and reading skills. Two (2) (20.0\%) of the teachers stated that essay writing enables pupils to acquire writing skills. The head teachers argued that question and answer, group discussion, storytelling and debate are the strategies which enable pupils to acquire some of the four basic skills in English language. More over the DEO explained that:

Question and answer, group discussion, and storytelling enable pupils to acquire the four basic skills in English language. By using these strategies pupils are able to listen, speak, read and write. For example, by using group discussion pupils get an opportunity to listen when one explains his or her idea, speaking when explaining or contributing their views, writing when taking notes on what others are saying and reading from what they wrote. The four basic skills enable pupils to develop confidence and perform well in their studies. (13th July, 2018)

The findings show that strategies such as question and answer, group discussion, essay writing, drama and storytelling are used to enable pupils to acquire four basic skills in English language. This implies that participatory strategies used by teacher of English enable pupils to listen, speak, read and write. When pupils acquire the four basic skills, they easily understand the subject matter and develop confidence in English language hence good performance on PSLE. These findings are supported by Omari (1995) who insists that, language teachers have to use a variety of teaching and learning strategies such as copying notes, working on problems, peer teaching, quizzes and field work. Omari also emphasizes on the importance of teacher's creativity, imaginative curiosity, and visionary resourcefulness and as facilitators of learning.

\subsubsection{Teaching Strategies That Enhance Pupils' Performance on PSLE in English Language Subject}

The study investigated about teaching strategies which enhance pupils' performance on PSLE in English language subject in public primary schools in Magu District. The responses of teachers are presented in the following Table 4. 


\begin{tabular}{|c|c|c|}
\hline Teaching Strategies & Frequency (f) & Percent (\%) \\
\hline Group discussion & 6 & 60.0 \\
\hline Question and answer & 6 & 60.0 \\
\hline Drama & 1 & 10.0 \\
\hline Demonstration & 1 & 10.0 \\
\hline Songs & 1 & 10.0 \\
\hline Chain drilling & 1 & 10.0 \\
\hline Role play & 1 & 10.0 \\
\hline Debate & 1 & 10.0 \\
\hline Peer sharing & 1 & 10.0 \\
\hline Essay writing & 1 & 10.0 \\
\hline
\end{tabular}

Table 4: Responses of Teachers of English on Teaching Strategies That

Enhance Pupils' Performance on PSLE in English Language Subject ( $\mathrm{N}=10$ )

Source: (Field Data, 2018)

The findings indicate that $6(60.0 \%)$ of the teachers of English stated that use of question and answer enhances pupils' performance on PSLE in English language subject while six (6) $(60.0 \%)$ of the teachers argued that group discussion enhances pupils' performance on PSLE in English language subject. Furthermore, majority of head teachers responded that use of question and answer and group discussion enhances pupils' performance on PSLE in English language subject. However, the DEO explained that: It depends on the class, so the teacher can choose strategies which can help the class to understand the lesson. But strategies such as question and answer, demonstration and group discussion enhance pupils' performance if utilized well by teachers of English during teaching and learning. (13 th July, 2018)

The pupils also stated that strategies which enhance their performance are question and answer, group discussion, demonstration and peer sharing. The findings from the study indicate that question and answer, group discussion, demonstration and peer sharing are the strategies that enhance pupils' performance on PSLE in English language subject. Utilization of various strategies led pupils to participate actively in a range of activities during teaching and learning process. Strategies that involve pupils in different activities during teaching and learning enhance pupils' performance on PSLE in English language subject. The pupils seem to be aware of more relevant activities than their teachers.

According to Savignon (2011), English language teaching and learning activities which enhance English competences involve learners effectively in the lesson and help learners to communicate fluently in English and therefore perform better in English language subject.

\subsubsection{Other Strategies Used to Enhance Pupils' Performance on PSLE}

Apart from classroom strategies the study also investigated on other strategies which enhance pupils' performance on PSLE in public primary schools in Magu District. Table 5 indicates the responses from teachers of English.

\begin{tabular}{|c|c|c|c|c|c|c|c|c|c|c|}
\hline \multirow[t]{2}{*}{ Strategy } & \multicolumn{2}{|c|}{ Very often } & \multicolumn{2}{|c|}{ Often } & \multicolumn{2}{|c|}{ Sometimes } & \multicolumn{2}{|c|}{ Rarely } & \multicolumn{2}{|c|}{ Never } \\
\hline & $\mathrm{F}$ & $\%$ & $\mathrm{~F}$ & $\%$ & $\mathrm{f}$ & $\%$ & $\mathrm{~F}$ & $\%$ & & $\%$ \\
\hline Remedial classes & 6 & 60.0 & 2 & 20.0 & 2 & 20.0 & - & - & - & - \\
\hline $\begin{array}{l}\text { Effective utilization of time } \\
\text { allocated for teaching }\end{array}$ & 3 & 30.0 & 7 & 70.0 & - & - & - & - & - & - \\
\hline Provision of homework & 6 & 60.0 & 2 & 20.0 & 2 & 20.0 & - & - & - & - \\
\hline Holiday tuition & 5 & $50 .-0$ & - & - & 1 & 10.0 & 4 & 40.0 & - & - \\
\hline Pupils' discussion & 6 & 60.0 & 1 & 10.0 & 1 & 10.0 & 1 & 10.0 & 1 & 10.0 \\
\hline Collaborative learning & 1 & 10.0 & 3 & 30.0 & 3 & 30.0 & 2 & 20.0 & 1 & 10.0 \\
\hline Prize giving & 1 & 10.0 & 2 & 20.0 & 4 & 40.0 & 2 & 20.0 & 1 & 10.0 \\
\hline $\begin{array}{c}\text { Creation of conducive learning } \\
\text { environment }\end{array}$ & 3 & 30.0 & 5 & 50.0 & 2 & 20.0 & - & - & & - \\
\hline Frequent tests & 7 & 70.0 & 3 & 30.0 & - & - & - & - & - & - \\
\hline English clubs & 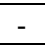 & - & - & - & 2 & 20.0 & 5 & 50.0 & 3 & 30.0 \\
\hline Revision of past papers & 8 & 80.0 & 2 & 20.0 & 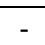 & - & - & - & - & - \\
\hline Providing feedback & 3 & 30.0 & 2 & 20.0 & 3 & 30.0 & 2 & 20.0 & - & - \\
\hline Discussing the assignments in class & 7 & 70.0 & 2 & 20.0 & 1 & 10.0 & - & - & - & - \\
\hline Interclass English speech day & 2 & 20.0 & - & - & 1 & 10.0 & 2 & 20.0 & 1 & 10.0 \\
\hline
\end{tabular}

Table 5: Other Strategies Used to Enhance Pupils' Performance on PSLE ( $N=10)$

Source: (Field Data, 2018)

Table 5 shows that $8(80.0 \%)$ of teachers of English answered that revision of past papers is used very often to enhance pupils' performance on PSLE. Seven (7) (70.0\%) of teachers of English argued that frequent tests are used very often to enhance pupils' performance on PSLE. Six (6) (60.0\%) of teachers of English pointed out that remedial class is used very often to enhance pupils' performance on PSLE. On the other hand, teachers of English stated that strategies such as English clubs and interclass English speech are never used to enhance pupils' performance on PSLE.

Majority of head teachers said that holiday tuition, remedial classes, frequent tests and revision of past papers are used very often. In addition, the DEO stated that: Remedial class, holiday tuition, inter school competition and grouping pupils 
according to their performance in the class are the strategies that are used very often to enhance pupils' performance in Magu District. (13th July, 2018).

The pupils also argued that revision of past papers, remedial classes, frequent tests and provision of homework are strategies that used very often.

The findings show that other strategies such as revision of past papers, frequent tests, remedial class and holiday tuition are employed very often while English clubs is never used to enhance pupils' performance on PSLE. Teachers of English use other strategies to support classroom teaching strategies in order to enhance pupils' performance on PSLE. These strategies have been planned by the schools and the District education office so as to ensure that pupils are concentrate much on studying. Most of the schools involved in the study use these strategies to enhance pupils' performance on PSLE, but few schools do not apply some of these strategies, for example, teaching remedial classes.

The findings concur with the findings of Mwamwenda (2004) who points out that, a competent teacher normally understands his/ her class hence organizes the strategies which are capable of enhancing learning to learners according to students' level and ages. According to Brown (2007), there is a depending and subordinating relationship between teaching and learning. Teaching plays a role as guiding, facilitating learning and encouraging the learner and setting the conditions for learning. Having a good understanding of how the learner learns will help teachers determine their philosophy of education, their teaching style, approach, methods and classroom techniques.

\subsection{Challenges Teachers of English Face in Using the Strategies}

The study investigated challenges which teachers of English, pupils, head teachers and DEO face on improving pupils' performance on PSLE in English language subject.

\subsubsection{Challenges Teachers of English Face in Applying the Strategies}

The study explored about challenges teachers of English face in the application of teaching strategies. Table 6 shows the responses from teachers of English.

\begin{tabular}{|c|c|c|}
\hline Challenges & Frequency (f) & Percent (\%) \\
\hline Large classes & 2 & 20.0 \\
\hline Pupils' use of mother tongue & 6 & 60.0 \\
\hline $\begin{array}{c}\text { Pupils' low participation during the lesson due to misunderstanding of } \\
\text { English language }\end{array}$ & 8 & 80.0 \\
\hline Shortage of teaching and learning resources, for example textbooks & 8 & 80.0 \\
\hline Pupil's negative attitude towards English language subject & 1 & 10.0 \\
\hline
\end{tabular}

Table 6: Responses of Teachers of English on Challenges They Face in Using the Strategies ( $\mathrm{N}=10)$ Source: (Field Data 2018)

Table 6 indicates that, majority 8 (80.0\%) of teachers of English said that pupils' low participation during the lesson due to failure to understand the language is a challenge in using participatory strategies during the lesson. Eight (8) $(80.0 \%)$ of teachers of English answered that shortage of teaching and learning resources, for instance, textbooks are a challenge for teachers of English to apply participatory strategies in teaching and learning process. Six (6) (60.0\%) of the teachers of English stated that pupils' mostly use of mother tongue affects learning and use of English language.

The head teachers said that shortage of teaching and learning resources, big classes, frequent use of mother tongue and Kiswahili which lead pupils to fail to practice speaking English language, lack of in-service training to teachers of English and pupil's negative attitude towards English language subject hinder the application of the strategies during the lesson. On the same question DEO argued that:

Poor foundation of English language for pupils, shortage of teaching and learning resources such as English textbooks and large classes are challenges that teachers of English face in applying the strategies. (13th July, 2018)

The pupils stated that shortage of textbooks and large classes whereby the teacher of English fails to attend to individual pupil during the lesson are challenges for teachers of English in the application of participatory strategies. A pupil from one of the schools said that:

Due to misunderstanding of English language, participation of pupils during the lesson is low. For example, pupils fail to ask or answer questions during the lesson even if the teacher gives them a chance to ask questions. (25 $5^{\text {th }}$ July, 2018).

The researcher observed teachers of English teaching in classrooms where teachers requested pupils to answer and ask questions but participation of pupils in the lessons was low in most of the classes observed. Due to low participation of pupils during the lesson, some teachers of English had to switch from English language to Kiswahili language in order to have pupils understand the subject matter. Teachers of English used code switching during the lesson when they wanted to clarify more about what they had taught after seeing that pupils did not understand. Pupils also used code switching. Large classes in some schools were also noted.

Through document analysis it was discovered that there is a shortage of teaching and learning resources especially English textbooks for standard seven in most of the schools. Teachers of English are using different textbooks from one school to another. The textbooks which are available are inadequate. In some schools, only reference books are used to teach English language subject in standard seven. Although teachers of English use participatory teaching strategies, these challenges can hinder the use of these strategies and therefore teachers of English may fail to get good results on PSLE in English language subject. 
The findings concur with the findings of Ogata (2012) who stated that, the provision of textbooks and other teaching and learning materials in developing countries continues to be inadequate. Supplementary reading materials are even harder to find although it is a requirement and recommended that teachers must have access to teaching materials for classroom instruction. Students as well must have access to learning materials for reading and practice. Vuzo (2010) revealed that teachers are using Kiswahili to explain points to students, highlight new information and provide definitions of concepts that are difficult for learners to grasp in English. The school quality assurance should deal with the problem by guiding the teachers of English to correct the situation. O'Connor and Geiger (2009) pointed out that, large classes which hinder effectiveness of English language teaching and strategies, limited resources such as English language textbooks, inadequate commitment of learners to use English language and need of additional training were the challenges that face primary school educators on English as a second language for learners in the Western Cape.

\subsubsection{Challenges Pupils Encounter in Learning English Language Subject}

The study investigated on challenges pupils encounter in learning English language subject. During interview with head teachers, they said that there is shortage of English textbooks for standard seven in the schools, use of mother tongue and Kiswahili languages which affect learning of English language, pupils have a poor foundation of English language that lead them to fail to understand the subject. Pupils also have negative attitude towards English language subject, there is shortage of competent teachers of English and the classes are too big for the teacher to attend to individual pupil during the lesson.

On the same opinion the DEO pointed out that:

Poor school attendance, pupil's poor base of English language and pupil's negative attitude on English language subject are the challenges pupils encounter in learning English language subject in public primary schools. (13 th July 2018) Moreover, pupils argued that shortage of text books, negative attitude towards English language subject whereby pupils think that English language is difficult to learn and it has no importance in their life; and large classes that led to noises during the lesson and failure of pupils to get help from the teacher are some of the challenges they face in learning English language.

Some public primary schools in Magu District have up to 80 pupils or even more in a class. Such numbers hinder the use of learner-centered strategies which require teachers' attention to all the pupils. English is only reinforced by teachers of English and specifically during the lesson, but the medium of communication outside the class is Kiswahili and Mother Tongue. These challenges hinder the use of teaching strategies that teachers of English use in teaching English language subject. Hindrance to teaching strategies could lead to failure of implementation of English language subject. The factors could affect performance on PSLE in English language subject and even in other subjects.

The findings are similar to UsoJuan's (2006) who points out that the learners' negative attitude toward English poses a great barrier for effective teaching. This negative attitude emanates from the fact that learners have limited competence in the language therefore preventing them from actively participating in classroom activities. Given that English is either a second or third language to some learners, most of them have difficulties in comprehending its structures. According to Edwards (1994), learners' negative attitudes pose additional barriers for teachers to tackle in their strategies for teaching and learning English in this complex multilingual environment. Dhillon and Wanjiru (2013) found out that there was lack of a joint commitment towards teaching English; teacher shortages in primary schools and pupils' negative attitudes towards learning English.

\subsubsection{Challenges Head Teachers Face on Improving Pupils' Performance on PSLE}

The study examined challenges head teachers face on improving pupils' performance on PSLE in English language subject. Head teachers said that there is shortage of competent teachers of English, shortage of English language textbooks, truancy among pupils which cause teachers of English to fail to meet the subject objectives set. Pupils' poor foundation of English language and frequent use of mother tongue hinders pupils to express themselves in English language. This indicates that these challenges hinder the head teachers when dealing with the improvement of pupils' performance on PSLE in English language subject in their schools.

Tella, Indoshi and Othuon (2010) revealed that English lessons have minimal learner participation because learners do not have the necessary competence which was not developed during their formative years. This minimal learner participation can be linked to the learners' negative attitude toward the subject which eventually leads to significant levels of underperformance in the English language.

\subsubsection{Challenges DEO Face on Improving Pupils' Performance on PSLE}

The study examined about challenges DEO face on improving pupils' performance on PSLE in English language subject in Magu District. During interview DEO responded by saying that: There is shortage of competent teachers of English, teaching and learning resources and large classes in the schools. There is a shortage of funds to conduct seminars or workshops for teachers of English and shortage of transport for the department for follow up. (13th July, 2018)

The findings indicate that shortage of competent teachers of English and teaching and learning resources, large classes in schools, shortage of funds for conducting seminars and shortage of transport for follow up activities are the challenges that DEO face on improving pupils' performance on PSLE in the District. The success of teaching and learning of English language subject depends on the availability of teaching and learning resources. Teachers of English and pupils need to be provided with necessary resources to accomplish the goals of teaching and learning English language subject. The findings are supported by UNESCO (2005) report which indicates that in sub-Saharan Africa and parts of Asia, large class sizes continue to impede the achievement of EFA goals especially in regard to quality education. Nande (2006) also 
stated that many teachers of English who are teaching the subject are not competent. Very few of them are really competent for teaching this subject. They have defective pronunciation. They have hardly a satisfactory command over English.

\subsection{Solutions to Challenges Teachers of English Face in Application Of Strategies}

Solutions to challenges were examined in relation with the challenges which teachers, pupils, head teachers and DEO face to enhance pupils' performance on PSLE.

\subsubsection{Solutions to Challenges Teachers Face in Use of Strategies}

The study investigated the solutions to challenges teachers face in use of strategies. Table 7 indicates the responses that teachers provided.

\begin{tabular}{|c|c|c|}
\hline Solutions & Frequency (f) & Percent (\%) \\
\hline Encourage pupils to learn and speak English & 6 & 60.0 \\
\hline Creation of conducive learning environment & 1 & 10.0 \\
\hline Use of reference books & 3 & 30.0 \\
\hline School support on availability of teaching and learning materials & 4 & 40.0 \\
\hline Use of simple English language and objects to enable pupils to \\
understand the lesson & 1 & 10.0 \\
\hline Use of English instead of Kiswahili during the lesson & 1 & 10.0 \\
\hline To divide pupils into small classes & 1 & 10.0 \\
\hline
\end{tabular}

Table 7: Responses of Teachers of English on Solutions to Challenges

They Face In Use of Strategies ( $\mathrm{N}=10)$

Source: (Field Data 2018)

From the research data, 6 (60.0\%) of teachers of English said that pupils are encouraged to learn and speak English, $4(40.0 \%)$ of teachers of English pointed out that the school should support the availability of teaching and learning materials. One (1) (10.0\%) of teachers of English responded that teachers should use English language instead of Kiswahili language during the lesson.

Head teachers pointed out that, pupils are encouraged to learn and speak English language, reference books are used to teach English language subject in standard seven and in order to reduce the number of pupils in classes, new classes should be built. The DEO argued that: The Government should provide English language textbooks, build new classrooms and provide funds for workshops and seminars that can be conducted in order to update teachers of English hence effective application of strategies in teaching English language subject. (13 th July, 2018)

Furthermore, pupils stated that learners should be encouraged to learn and speak English at school and during the lesson, and the school should provide teaching and learning resources such as text books. This shows that by using these solutions, teachers of English will effectively utilize the strategies that enhance pupils' performance on PSLE in English language subject.

\subsubsection{Solutions to Challenges Pupils Encounter in Learning English Language Subject}

Majority of head teachers claimed that pupils are advised to learn English as other subjects. Use of reference books, motivate pupils who do better in the examination and advice parents who can afford to buy English text books for their children to do so are the solutions to challenges that pupils encounter in learning English language subject. The DEO also said that, pupils are encouraged to learn English language. Furthermore, pupils stated that parents should be advised to buy English language textbooks for their children. A pupil from one of the schools added that: Pupils with negative attitude towards English language subject need to be advised and persuaded to learn the subject because it is important in their life. For example, English is a medium of instruction in secondary schools where these pupils will join if they will be selected after passing the PSLE. Likewise, to encourage those who are disappointed by thinking that English is a difficult language. (25th July, 2018)

The findings show that these solutions can help teachers of English to use participatory strategies that enhance pupils' performance on PSLE in English language subject. Instead of using reference books that differ from one school to another and which do not correlate to the syllabus, the government needs to provide English language textbooks to schools. Availability of teaching and learning resources and ability of pupils to speak English enable teachers of English to apply participatory teaching strategies that enhance pupils' performance on PSLE.

\subsubsection{Solutions to Challenges Head Teachers Face on Improving Pupils' Performance}

The study examined the solutions to challenges head teachers face on improving pupils' performance on PSLE. The findings show that provision of in-service training, provision of teaching resources, motivation to teachers of English language who work hard are the solutions for challenges that head teachers face on improving pupils' performance on PSLE in English language subject in Magu District.

The findings are supported by Joyce and Shower (2002) who said that, teachers of English need to be up-to-date with the new teaching and learning strategies and how to use them effectively. To be effective, professional development should base on curricular and instructional strategies that have a high probability of affecting students' ability to learn. 


\subsubsection{Solutions to Challenges DEO Face on Improving Pupils' Performance on PSLE}

The study investigated on the solutions to challenges the DEO face on improving pupils' performance on PSLE. The findings from the study show that the solution for these challenges is in the hands of the government as the DEO stated:

To solve all these challenges the government should empower the District by providing enough funds for education activities in the District. Pupils' performance on PSLE in English language subject can increase if in-service training and seminars will be provided to teachers of English language. Teaching and learning resources should be available in order to improve pupils' performance on PSLE. Although the government has been providing funds to the department of education in Magu District, the funds provided are insufficient compared to the needs in education department within the District. (13'th July, 2018)

The findings show that the District needs big support from the government to ensure that in-service training for teachers of English, English textbooks and other education services needed in public primary schools are provided. Therefore, the government needs to provide sufficient funds for education services to enhance pupils' performance on PSLE in Magu District. Provision of these services will enable effective utilization of teaching strategies to enhance pupils' performance on PSLE in English language subject in Magu District.

The findings from the study are in agreement with the findings of Nyamubi (2003) who argued that the availability of teaching and learning materials and a well supervised learning environment contribute to students' good performance.

- Ho: There is no significant relationship between strategies used by teachers of English and pupil's performance on PSLE in public primary schools in Magu District.

- H1: There is a significant relationship between strategies used by teachers of English and pupils' performance on PSLE in public primary schools in Magu District.

\begin{tabular}{|c|c|c|c|}
\hline & Value & Df & Asymp. Sig. (2-Sided) \\
\hline Pearson Chi-Square & $6.875^{\mathrm{a}}$ & 2 & .032 \\
\hline Likelihood Ratio & 8.962 & 2 & .011 \\
\hline Linear-by-Linear Association & 5.625 & 1 & .018 \\
\hline N of Valid Cases & 10 & & \\
\hline
\end{tabular}

Table 8: Chi- Square Summary Table for Hypothesis Testing

Source: (Field data, 2018)

a. 6 Cells (100.0\%) Have Expected Count Less Than 5, the Minimum Expected Count Is 1.20.

From Table 8, the calculated P-value was 0.032 which was less than the significance level of 0.05 . Therefore, the null hypothesis was rejected. Hence, there is a significance relationship between strategies used by teachers of English and pupil's performance on PSLE in public primary schools in Magu District.

\section{Conclusions and Recommendations}

\subsection{Conclusions of the Study}

With regard to the research findings, hypothesis and literature review the researcher comes up with the following conclusions. The findings indicate that, in Magu District teachers of English use learner centred teaching strategies such as question and answer, group discussion and demonstration that enhance pupils' performance on PSLE. However, application of these strategies face challenges such as shortage of teaching and learning resources, lack of in- service training for teachers of English and large classes which led the strategies to be ineffective. The results from hypothesis testing show that there is a link between learner centred strategies used by teachers of English and pupils' performance on PSLE in English language subject. Likewise, from literature review, other scholars such as Savignon (2011) and Riffer (2012) found out that learner-centred strategies enhance pupils' performance in English language subject.

Thus, learner centred strategies used by teachers of English in public primary schools enhance pupils' performance on PSLE in English language subject in Magu District. The hypothesis tested confirmed that there is a significant relationship between strategies used by teachers of English and pupil's performance on PSLE in public primary schools in Magu District.

\subsection{Recommendations}

The following recommendations have been made:

- Education stakeholders should build classrooms in schools so as to reduce high population of pupils in classes.

- Ministry of Education, Science and Technology should plan to provide in- service training and seminars to teachers of English in public primary schools in order to enable teachers to be up-to-date in using teaching strategies so as to enhance pupils' performance on PSLE.

- Ministry of Education, Science and Technology should provide sufficient teaching and learning resources to the districts to enable effective teaching and learning in public primary schools.

- Parents should be advised to buy learning resources which are not available at schools for their children.

- Teachers of English should use numerous teaching strategies so as to enhance pupils' performance on PSLE in English language subject.

- This study was carried out in Magu District; similar study can be carried out in other areas in order to see if researchers can make generalization of the results. 
- Finally, the further research can be comparative study of the same topic but involving private and public primary schools.

\section{References}

i. Adunola, O. (2011). The Impact of Teachers' Teaching methods on the Academic Performance of Primary School Pupils in Ijebu-Ode Local cut Area of Ogun State. Ogun State, Nigeria: Ego Booster Books.

ii. Association for the Development in Africa. (ADEA) (2005). Conference on Bilingual Education and the use of Local Languages in Education. International Education Journal, 17(2), 1-5.

iii. Bell, D. and Bogan, B. (2013) "English Language Learners: Problems and Solutions Found in the Research of General Practitioners of Early Childhood" e-Journal of Balanced $\quad$ Reading Instruction 1(2), article 5.

iv. Biswalo, T.A. (2010). Policy Processes in Relation to Language in Tanzania: Examining Shifts in Language Policy. Urbana, Illinois: University of Illinois.

v. Brown, H. D. (2001). Teaching by Principles: An Interactive Approach to Language Pedagogy: New York. Addison Wesley Longman, INC.

vi. Dembo, M. H. (1991). Applying Educational Psychology in Classroom. $4^{\text {th }}$ Edition. California: Longman.

vii. Dhillon, J. K. \& Wanjiru, J. (2013). Challenges and Strategies for Teachers and Learners of English as a Second Language: The Case of an Urban Primary School in Kenya. Retrieved on 29th August 2018 from https:// www researchgate. net/ publication/268515741

viii. Edwards, J. (1994). Multilingualism. London and New York: Routledge.

ix. Fahraeus, A. W. E. (2013). Learner-centered teaching: Five key changes to practice. Book Review. Journal of the Scholarship of Teaching and Learning. 13 (4), 1-6. [8] Li, N. (2012).

x. Joyce, B. R. \& Shower, B. (2002). Student Achievement through staff Development. New York: Ascd

xi. Malekela, G. A. (2003). English as a Medium of Instruction In post-Primary Education in Tanzania: Is it a fair policy to the Learners'? In: Brock-Utne, B., Tanzania and South Africa. (LOITASA). Dar es Salaam: E\&D Limited.

xii. Mesomapya, J. (2016, October 27). Performance in Kiswahili, English and Mathematics decline in Tanzania's standard seven examinations. The citizen

xiii. Metto, E. \& Makewa, L. N. (2014). "Learner-Centered Teaching: Can It Work in Kenyan Public Primary Schools?" American Journal of Educational Research, vol. 2, no. $\quad$ 11A: 23-29. doi: 10.12691/ education-2-11A-4.

xiv. Mutai, M. N. (2012). An Assessment of the Teaching Strategies Employed by English Language Teachers in Eldoret Municipality, Kenya. Journal of Emerging Trends in Educational Research and Policy Studies (JETERAPS) 3(3): 352-357

xv. Mwamwenda, T. S. (1995). Educational Psychology: An African Perspective. London: Heinemann Bulter woth Publishers Ltd

xvi. Nande, V. K. (2006). Teaching of English. New Delhi: An mol publications Pvt.LTD.

xvii. NECTA. (2009). PSLE results. Retrieved 03.02.2018, from The National Examination Council of Tanzania http:// www. necta.go.tz/matokeo/ 2009/psle/ index.htm

xviii. Nyamubi, G. J. (2003). Attitudinal and Motivational factors Influencing Performance in English Language among Tanzania Secondary School Students, Unpublished MA (Ed) Dissertation, University of Dar es Salaam.

xix. O'Connor, J. \& Geiger, M. (2009). Challenges Facing Primary School Educators of English Second (or Other) Language Learners in the Western Cape. South African Journal of Education. Vol. 29: 253-269

xx. Ogata, B. (2012). Influence of teaching and learning materials on children performance in pre-schools in Borabu District, Nyamira County, Kenya. Department of Educational Administration and Planning. University of Nairobi.

xxi. Omari, I. M. (1995). Conceptualizing Quality in Primary Education. Papers in Education and Development, vol. 16, 25-48

xxii. Riffer, H. (2009). Self Perceived English Proficiency in Relation to Extramural Language Environment. London: Karlstad University

xxiii. Roy -Campbell, Z. M. \& Qorro, M. P. (1997). Language Crisis in Tanzania: The Myth of English Versus Education: Dar es salaam: Mkuki na Nyota Publishers.

xxiv. Savignon, S. (2011). Communicative Language Teaching: Context and Concerns in Teacher Education. New Haven CT. Yale University Press

xxv. Shi, H. (2015). Exploring English Language Learners' Needs and Learning Strategies in the University Setting. Institute of Learning Styles Journal. Vol. 1. 30

xxvi. Tella, J., Indoshi, F. C., and Othuon, L. A. (2010). Relationship between students' perspectives on the secondary school English curriculum and their academic achievement in Kenya. Educational Research. 1, 390-395.

xxvii. United Republic of Tanzania, (URT), (1995). Education and training policy. Government Print. Or Dar es salaam.

xxviii. UNESCO (2005). Challenges of implementing free primary education in Kenya: assessment report.Kenya. Nairobi: Ministry of Education, Science \& Technology.

xxix. Usó Juan, E. (2006). Current Trends in the Development and Teaching of the Four Language Skills. Berlin, New York: M. de Gruyter.

xxx. Uwezo. (2011, 2012, 2013). Are Our Children Learning? Annual Learning Assessment Report. Dar es Salaam: TEN/ TEM Publications.

xxxi. Uwezo at Twaweza. (2015). "Are our children learning? The state of education in Tanzania in 2015 and beyond." http:/ / twaweza.org/go/ uwezo-tz-2014 
xxxii. Vuzo, M. (2010). Exclusion through Language: A Reflection on Classroom Discourse in Tanzanian Secondary Schools. Papers in Education and Development, 29, 14-36.

xxxiii. World Bank. (2014). Tanzania - Big Results Now in Education Program Project. Washington, DC: World Bank Group.

xxxiv. Yohana, E. (2012). Effects of Language of Instruction on Students' Performance in

English: Experience from Secondary Schools in Dodoma. Retrieved on 23 ${ }^{\text {rd }}$ March from www.amazon.com 